\title{
Occurrence of Psocoptera in boreal old-growth forests
}

\author{
Jussi Kanervo \& Gergely Várkonyi
}

\begin{abstract}
Kanervo, J. \& Várkonyi, G. 2007: Occurrence of Psocoptera in boreal oldgrowth forests. - Entomol. Fennica 18: 129-137.

We aim to assess habitat and host-tree preferences of psocids (Insecta: Psocoptera) sampled in old-growth-forest biodiversity studies conducted during 1997-2003 in central and southern Finland. Thirty-one out of the recognized sixty-nine Finnish species were found in the samples, four of which (Elipsocus abdominalis, Reuterella helvimacula, Stenopsocus lachlani and Trichadenotecnum majus) might be associated with old-growth forests or with old trees. Psocidus flavonimbatus, a rare taiga species only previously known from the $19^{\text {th }}$ century holotype from Estonia, was repeatedly collected in Kuhmo region, eastern Central Finland. This species is possibly associated with boreal spruce-dominated old-growth forests and likely to prefer Norway spruce as a host tree. We also provide new distribution data for several species and discuss their host-tree preferences.
\end{abstract}

\begin{abstract}
Jussi Kanervo, Zoological Museum, University of Turku, 20014 Turku, Finland Gergely Várkonyi (corresponding author), Kainuu Regional Environment Centre, Friendship Park Research Centre, Lentiirantie 342 B, 88900 Kuhmo, Finland; E-mail address: gergely.varkonyi@ymparisto.fi
\end{abstract}

Received 20 July 2006, accepted 24 August 2006

\section{Introduction}

Boreal coniferous forests comprise one of the largest vegetation zones on the Earth. During the past 100 years, industrial forestry has altered and fragmented boreal forests in Europe at an accelerating rate (Esseen et al. 1997, Aksenov et al. 1999). More than $95 \%$ of natural forests in Finland are under intensive management (e.g. Aksenov et al. 1999), and such extensive habitat loss, isolation and deterioration have endangered a number of species specialized on natural forests. In fact, forest management has been responsible for the national-level extinction of $36 \%$ of the species already lost from the Finnish fauna and flora, the respective percentages being 63 and 50 for currently threatened (combined IUCN Red List Categories CR, EN and VU) and near-threat- ened (NT) species (Rassi et al. 2001). Moreover, many forest species currently categorized as of least concern (LC) live in small, more or less isolated populations that may have to pay the extinction debt (Tilman et al. 1994, for a review see Hanski 2005) of their recently diminished habitats. Hence, figures provided by Rassi et al. (2001) are likely to be underestimates of true levels of species endangerment.

Though knowledge of the biodiversity of many habitats, including forests, has recently been increasing, e.g. due to the substantial research effort coordinated by the Finnish Biodiversity Research Programme FIBRE during 1997-2002 (Markkanen et al. 2002), further studies are needed to reveal the habitat requirements of many forest-dwelling organisms. For both successful species conservation and sustain- 
able forest management it is essential to recognize, which species are restricted to or dependent on old natural forests and what are the population biology characteristics of these species, including rates of reproduction, dispersal, colonization and local extinction.

Psocids (Insecta: Psocoptera) have not been previously studied in the boreal old-growth-forest biodiversity context. The Finnish psocid fauna is relatively well known (Kanervo 1996, 1997, 2002, Lienhard 1998, Lienhard \& Kanervo 2002) and found to be species-poor, currently consisting of only 69 recognized species (Kanervo 2002, Lienhard \& Smithers 2002). The Finnish fauna has been considered to be composed of Central European species, lacking exclusively boreal or arctic elements (Lienhard 1998). However, the original ecosystems of northern Europe (including the Nordic countries and Northwest Russia), such as natural forests and forested mires, have not been systematically studied.

To get a better understanding of the occurrence of old-growth-forest inhabiting psocids, we sampled populations dwelling in latesuccessional-stage spruce-dominated natural and natural-like forests (to be referred to as oldgrowth forests, OGF) in central and eastern Finland during 1997-2003. We used several sampling methods to detect as many species as possible. For comparison with the occurrence of psocids in managed forests we use habitat preference data published by Laine et al. (1993) and a large unpublished data set based on observations by one of us (JK). We aim to assess the habitat preferences of psocid species sampled in old-growth forests and to classify these species into one of the following categories: (i) true OGF species, (ii) species preferring old trees, and (iii) species with no such preferences. We also report on some faunistic and ecological findings of forest-dwelling psocids.

\section{Material and methods}

Sampling was carried out in the framework of two separate studies, both belonging to the research project BIOBOF (BIOdiversity in BOreal Forests) led by professor Ilkka Hanski, Univer- sity of Helsinki, and coordinated by the Finnish Biodiversity Research Programme FIBRE (Markkanen et al. 2002). BIOBOF studies were conducted as joint projects of Friendship Park Research Centre (Kainuu Regional Environment Centre), professor Hanski's Metapopulation Research Group (University of Helsinki) and senior researcher Juha Siitonen from the Finnish Forest Research Institute.

In the first study, entitled 'Species diversity in small old-growth forest fragments: the effect of the time since isolation' (here to be referred to as 'Fragmentation study'), there were two distinct study areas. In Kainuu, eastern Finland, 18 small (3-13 ha) spruce-dominated OGF fragments and five large $(>100 \mathrm{ha})$ old-growth forests were sampled in 1997, while in North Häme, southern Finland, 18 similar-quality forests with a much wider range of area (2-390 ha) were sampled in 1998 (Fig. 1). The area of the actual sampling plots was 9 ha $(300 \mathrm{~m} \times 300 \mathrm{~m}$ square $)$, or, if the fragment was smaller than 9 ha, the sampling plot covered its area entirely. Sampling periods were 3.VI. to 7.X.1997 in Kainuu and 25.V. to 15.X. 1998 in Häme.

The sampling design consisted of five standard window traps, two sugar-bait traps and one black-light trap in each of the plots, except for three remote plots in Kainuu where light traps could not be employed for logistic reasons. The window traps consisted of two perpendicular, intercepting thin transparent plastic panes fitted with a funnel beneath leading to a plastic collecting jar containing a solution of water, salt and detergent. The sugar-bait traps (Jalas 1991) consisted of a water-resistant roof covering a wide funnel leading down to a plastic bucket. A container with a piece of plastic foam saturated with the sugar-bait liquid was hung in the middle of the funnel. The fermented liquid contained light beer, white and brown sugar, honey, pieces of apple and yeast. The light traps (Jalas 1960) were fitted with a 12-V 8-W black-light tube-lamp (Philips TL8 W/08) powered by batteries charged by solar panels (Neste Advanced Power Systems, PVModule K32).

Traps were emptied during the entire sampling period every $2^{\text {nd }}$ to $3^{\text {rd }}$ week, and the insect material was sorted to the order level in Friendship Park Research Centre, Kuhmo, and sub- 


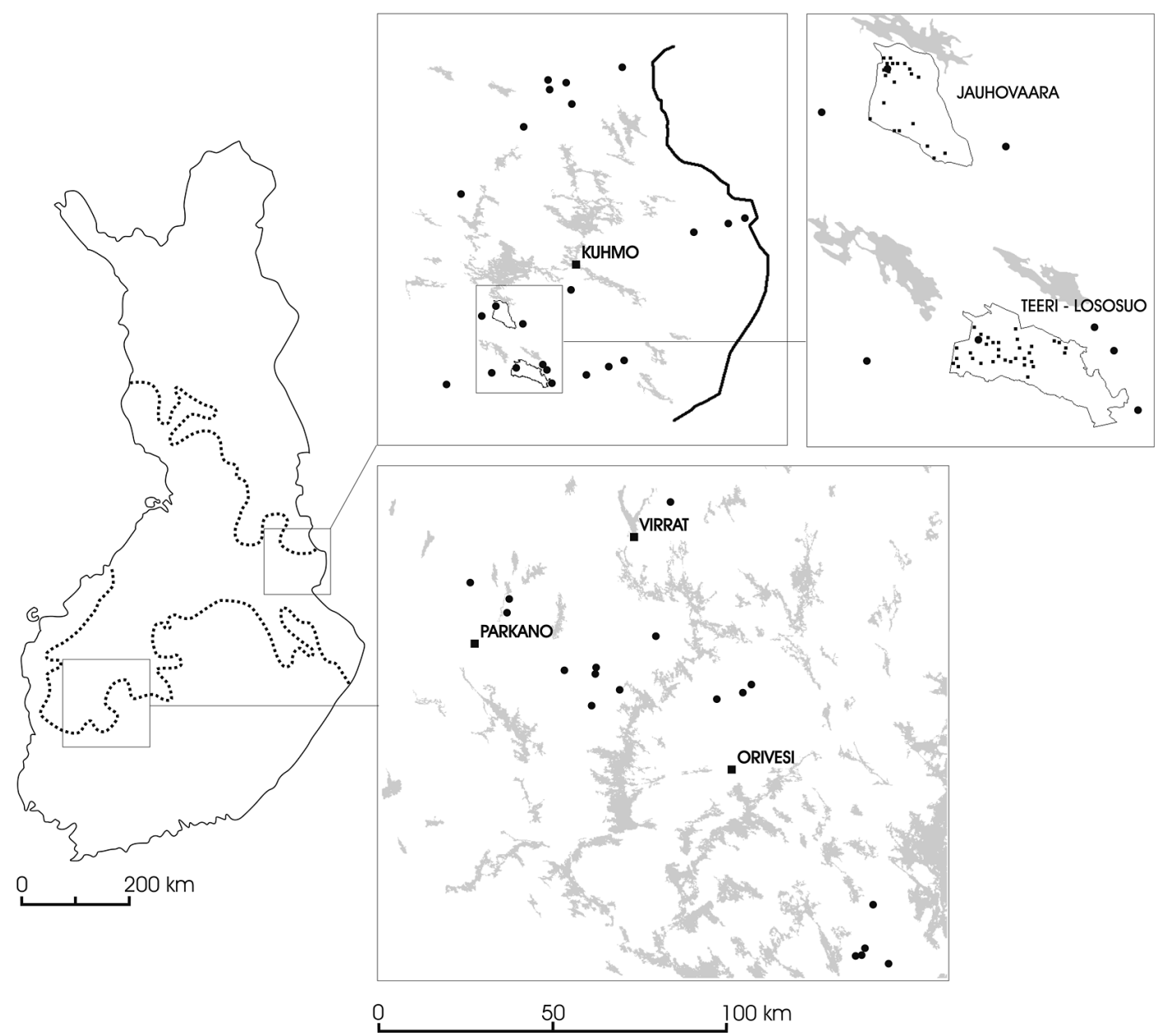

Figure 1. Map of the study areas showing sampling plots. Filled circles show the locations of the focal fragments of the Fragmentation study. The small squares in the Jauhovaara and Teeri-Lososuo areas in Kuhmo region denote the one-hectare squares with window traps on the trunks of standing aspen trees (Material and methods). The dotted line shows the approximate southern and northern borders of the middle-boreal forest zone in Finland.

sequently sent to specialists for identification. Unlike in Häme, psocid samples from Kainuu did not include window-trap material.

The second study, entitled 'Effects of landscape structure on the occurrence of insects specializing on trembling aspen Populus tremula L.', or the 'Aspen study', was carried out in Kuhmo, eastern Finland in 1998, 2000 and 2002-2003. In 1998, four window traps were fitted on the trunks of old trembling aspens situated in each of 35 and 21 one-hectare squares in the Jauhovaara and Teeri-Lososuo areas, respectively (Fig. 1). In 2000, a subsample of the aspen trees studied in
1998 in Teeri-Lososuo were resampled (nine sampling plots with four traps in each). The insect samples were separated to the order level and sent to experts for further identification. In 2002, one of the previous sampling plots was sampled on a single day by beating the foliage of different trees and collecting all psocids from a white sheet beneath the sample trees. This pilot sampling was repeated four times in one plot and three times in another plot in 2003. The psocid material collected by beating in 2002-2003 is referred to as the 'beating sample'. All psocid samples were identified by JK. The nomenclature used in the 
present paper follows Lienhard \& Smithers (2002).

The large reference data set is based on nonsystematic sampling of Psocoptera by JK (mainly using the beating method) from different habitats in SW Finland during 1994-2002. This area has a much longer history of human impact than southern and especially eastern Finland. Due to the intensive transformation of landscapes during the past hundreds of years, there are practically no OGF areas left in SW Finland. Another difference between the of the OGF samples and the reference material is that they represent different biogeographical zones; SW Finland belongs to the hemiboreal and, partly, to the southern-boreal forest zone, while the study areas in Häme and Kainuu both belong to the middle-boreal forest zone (Ahti et al. 1968). However, differences in climatic conditions and in vegetation between southern and central parts of Finland are likely to have little effect on psocid species composition, as most species are widespread over large geographical areas (Lienhard 1998). We therefore assumed differences in species compositions between the OGF material of the present study and the reference data by JK to refer to differences in forest quality rather than to climatic factors.

\section{Faunistic results}

A total of 3,794 adult psocid individuals were sampled altogether in the two studies. Thirty-one psocid species $(45 \%)$ of the 69 species reported from Finland were detected in at least one of the samples. In the Fragmentation study, 954 individuals representing 19 species from Kainuu and 814 individuals of 20 species from Häme were collected and identified. The respective numbers in the Aspen study were 1,605 individuals of 26 species, and in the beating sample 383 individuals of 20 species. Table 1 summarizes the psocid samples of this study. The bait traps used in the Fragmentation study collected only a total of 38 psocid specimens, which records we excluded from further analyses due to small sample size.

The most abundant species in Häme was Metylophorus nebulosus while in Kainuu the dominant species was Elipsosus abdominalis (Table 1). In this study, only 12 specimens of the latter species were found in Häme, which observation is consistent with strongly fluctuating populations known to occur in this species (JK, personal observations).

We next give an overview of interesting faunistic findings based on our OGF psocid material:

Liposcelis silvarum (Kolbe): species in this genus are apterous, hence the collecting methods employed in this study were not suitable for collecting a representative sample of this species. Only a single $L$. silvarum specimen was found (St: Parkano, Ahvenus 6888:329; window trap 29.VI.-15.VII.1998; M. Kuussaari, J. Siitonen \& M. Romppanen leg.). Liposcelis silvarum is widely distributed in Finland, found up to Lapland, Lkoc: Muonio (Meinander 1978). This is the first record in biogeographical province Satakunta.

Graphopsocus cruciatus (Linnaeus): First record for province Kainuu and northernmost specimens in Finland: Ok: Kuhmo, Teeri-Lososuo 7091:608, 2 exx. 1.VIII.-1.IX.2000 (G. Várkonyi, M. Salo \& M. Romppanen leg.). This species was earlier found only in southern Finland in provinces $\mathrm{Ab}, \mathrm{N}$ and $\mathrm{Ta}$ (M. Meinander, unpublished), but it is also known to occur in northern Sweden, LulPm (Hedström 1989).

Lachesilla quercus (Kolbe): This species has been found in Finland on the southern coast in provinces Ab (e.g. Kanervo \& Rinne 1996) and N (Vantaa, Seutula 669:38, 2 exx. reared from juveniles, June 2001, J. Kanervo leg.), as well as in central and northern Finland in provinces $\mathrm{Sb}(\mathrm{Sa}-$ volainen 2001), ObS and Ks (Laine et al. 1993). This is the first record for province Kainuu, Ok: Kuhmo. Altogether 15 specimens were sampled in Kuhmo, five of which were caught by sugarbait traps. As L. quercus is probably a fungivorous species (Günther 1974), it might be attracted to bait traps by fungi growing on the bait foams.

Elipsocus sp.: A single $\bigcirc$ was found in this material, Ok: Kuhmo, Teeri-Lososuo 7091:608, 1 ex., 24.VII.2003 (M. Salo leg.) on Picea abies. The identity of this species is uncertain at present: the subgenital plate is similar to that of Elipsocus hyalinus (Stephens), but the colour of the abdomen resembles that of E. moebiusi Tetens. However, the wings lack traces of spots and are hya- 
Table 1. Occurrence of psocids in the old-growth forest samples of this study and in the forest samples of Laine et al. (1993)*. Abbreviations in the column captions: Ka_L = Fragmentation study, Kainuu 1997, light traps; Hä_L = Fragmentation study, Häme 1998, light traps; Hä_W = Fragmentation study, Häme 1998, window traps; Ku_A = Aspen study, Kuhmo 1998 \& 2000, window traps; Ku_B = Kuhmo, beating samples 2002-2003; T_OGF = Taivalkoski, old-growth forest 1986-1987; NF_MF = Northern Finland, managed forests 1986-1988. For more details see Material and methods.

\begin{tabular}{|c|c|c|c|c|c|c|c|}
\hline Species & Ka_L & Hä_L & Hä_W & Ku_A & Ku_B & ${ }^{*} T$ OGF & ${ }^{*} \mathrm{NF} \_\mathrm{MF}$ \\
\hline \multicolumn{8}{|l|}{ Liposcelididae } \\
\hline Liposcelis silvarum (Kolbe) & & & 1 & & & & \\
\hline \multicolumn{8}{|l|}{ Caeciliusidae } \\
\hline Caecilius fuscopterus (Latreille) & 2 & 2 & 55 & 34 & 22 & & 4 \\
\hline Valenzuela flavidus (Stephens) & 2 & 1 & 9 & 91 & 13 & & 12 \\
\hline V. burmeisteri (Brauer) & 40 & 7 & 10 & 114 & 16 & 22 & 468 \\
\hline V. piceus (Kolbe) & & & 2 & & & & 1 \\
\hline V. gynapterus (Tetens) & & & & & 1 & & 1 \\
\hline V. despaxi (Badonnel) & 35 & 18 & & 9 & 50 & 6 & 66 \\
\hline Enderleinella obsoleta (Stephens) & & 6 & & & 29 & & \\
\hline \multicolumn{8}{|l|}{ Stenopsocidae } \\
\hline Graphopsocus cruciatus (Linnaeus) & & & & 2 & & & \\
\hline Stenopsocus immaculatus (Stephens) & 3 & 3 & 15 & 3 & 11 & & \\
\hline S. lachlani Kolbe & 62 & 21 & 39 & 165 & 41 & 35 & 77 \\
\hline \multicolumn{8}{|l|}{ Amphipsocidae } \\
\hline Kolbia quisquiliarum Bertkau & 1 & & & 4 & & & \\
\hline \multicolumn{8}{|l|}{ Lachesillidae } \\
\hline Lachesilla pedicularia (Linnaeus) & & & & & & & 3 \\
\hline \multirow{2}{*}{\multicolumn{8}{|c|}{ Peripsocidae }} \\
\hline & & & & & & & \\
\hline Peripsocus didymus Roesler & 135 & 66 & 11 & 25 & 58 & 2 & 3 \\
\hline P. alboguttatus (Dalman) & & & 1 & 53 & 14 & & 11 \\
\hline \multicolumn{8}{|l|}{ Elipsocidae } \\
\hline Cuneopalpus cyanops (Rostock) & & & & 2 & & & \\
\hline Elipsocus sp. & & & & & 1 & & \\
\hline E. abdominalis Reuter & 286 & 3 & 9 & 255 & 26 & & 221 \\
\hline Hemineura dispar Tetens & 7 & & & 8 & 4 & & \\
\hline Reuterella helvimacula (Enderlein) & 54 & 12 & 11 & 162 & 2 & 186 & 560 \\
\hline \multicolumn{8}{|l|}{ Philotarsidae } \\
\hline Philotarsus spp. ${ }^{1}$ & 109 & 101 & 60 & 102 & 29 & & 199 \\
\hline \multicolumn{8}{|l|}{ Mesopsocidae } \\
\hline Mesopsocus laticeps (Kolbe) & & & & & & & 6 \\
\hline Mesopsocus unipunctatus (Müller) & 68 & 4 & 1 & 141 & 5 & 2 & 34 \\
\hline \multicolumn{8}{|l|}{ Psocidae } \\
\hline Amphigerontia bifasciata (Latreille) & & & & 4 & & & 1 \\
\hline A. contaminata (Stephens) & & 1 & & & & & \\
\hline A. intermedia (Tetens) & & & & 8 & & & \\
\hline Neopsocopsis hirticornis (Reuter) & 1 & & & 2 & 1 & & \\
\hline Metylophorus nebulosus (Stephens) & 106 & 174 & 138 & 56 & 37 & & 19 \\
\hline Psococerastis gibbosa (Sulzer) & & & & 1 & & & \\
\hline Psocidus flavonimbatus (Rostock) & 1 & & & 37 & 3 & & \\
\hline Trichadenotecnum majus (Kolbe) & 39 & 10 & 17 & 238 & 20 & & 215 \\
\hline T. germanicum Roesler & 1 & 2 & & 49 & & & \\
\hline T. incognitum Roesler & & 4 & & 27 & & & \\
\hline Sum & 954 & 435 & 379 & 1,605 & 383 & 256 & 1,965 \\
\hline
\end{tabular}

1 The material of Fragmentation and Aspen studies includes at least Philotarsus picicornis (Fabricius) - but possibly also Ph. parviceps Roesler, a species that has not been yet reported from Finland. 
line, without the grey tone typical to E. moebiusi.

Amphigerontia intermedia Tetens: New to province Ok and northernmost Finnish records: Ok: Kuhmo: Jauhovaara 7106:603, 2 우 우 27.VII.-24.VIII.1998 (M. Kuussaari, H. Lappalainen and M. Romppanen leg.); Teeri-Lososuo 7091:608, 1ठ and 1 9 30.VII.-27.VIII.1998 (M. Kuussaari, H. Lappalainen and M. Romppanen leg.); Teeri-Lososuo 7091:608, 1 ภ 3.VII.-

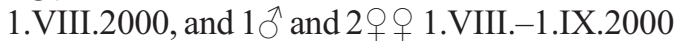
(G. Várkonyi, M. Salo \& M. Romppanen leg.). This species has been previously known to occur in Finland only in provinces Ab (Kanervo 1997) and Oa: Ilmajoki (Pirilänneva 6968:277, 1 ㅇ 26.VII.1996, Veli-Matti Mukkala leg.). In Russia, this species has been found, for example, in the Karelian Republic (Danks 1968).

Neopsocopsis hirticornis (Reuter): Records in this material: Ok: Sotkamo, Urpovaara, 7089:602, 30.VII.-11.VIII.1997, 1ठ (M. Kuussaari, H. Lappalainen and M. Romppanen leg.); Ok: Kuhmo Jauhovaara 7106:603, 19 27.VII.25.VIII.1998; Ok: Kuhmo, Teeri-Lososuo 7091: 608, 1 ð 27.VII.-25.VIII.1998 (M. Kuussaari, H. Lappalainen and M. Romppanen leg.) and $1 \hat{\delta}$ 25.VII.2003 on Picea abies (M. Salo leg.). In Sweden, this species is the only psocid that is reported to have a northern distribution (Hedström 1989), but in Finland it has been recently found on the southern coast (Ab: Turku, Uittamo 671:23, 18.VII.2002, 1 on Pinus sylvestris, J. Kanervo leg.).

Psococerastis gibbosa (Sulzer): This is the biggest psocopteran species reported from Fennoscandia (body length ca. $6 \mathrm{~mm}$ ). New to province Kainuu and northernmost record in Finland: Ok: Kuhmo, Teeri-Lososuo 7091:608, 1 우 1.VIII.-1.IX.2000 (G. Várkonyi, M. Salo \& M. Romppanen leg.).

Trichadenotecnum incognitum Roesler: This species has earlier been reported only from provinces $\mathrm{Ab}$, $\mathrm{Oa}$ and $\mathrm{Tb}$. New to provinces $\mathrm{Ok}$ (Kuhmo, Jauhovaara 7106:603 and TeeriLososuo 7091:608, altogether 27 exx. in 1998, northernmost records from Finland) and $\mathrm{Ta}$ (Lammi: Puukkohonka 6792:339, and Sudenpesänkangas 6789:340). This species has also been found as new to biogeographical provinces $\mathrm{St}$ and $\mathrm{Sb}$ (JK, unpublished data base).

Cuneopalpus cyanops (Rostock) and Hemi- neura dispar Tetens: New to province Ok (Kuhmo) and northernmost Finnish records.

Further species new to province Ok: Valenzuela flavidus (Stephens), V. burmeisteri (Brauer), Kolbia quisquiliarum Bertkau, Mesopsocus unipunctatus (Müller), Reuterella helvimacula (Enderlein) and Metylophorus nebulosus (Stephens). New species to provinces St and Ta: Enderleinella obsoleta (Stephens); new to provinces St and Tb: Stenopsocus immaculatus (Stephens); new to province St: Trichadenotecnum germanicum Roesler (St: Parkano, Ahvenus, 6888:329 and Nälkähittenkangas, 6892: 329); new to province Tb: Peripsocus didymus Roesler.

We now turn to some behavioural and biological findings made from our samples. First, on light-attraction of psocids, a topic with a small literature (but see e.g. Broadhead \& Wolda 1985). Light traps attracted many males of Peripsocus didymus. Other species with a clear attraction to black-light were Valenzuela despaxi, Philotarsus spp. and Metylophorus nebulosus (Table 1). In turn, Peripsocus alboguttatus was not lighttrapped at all, even though 54 specimens were caught by window traps and 14 by beating, suggesting a light-avoidance behaviour in this species.

Second, on further evidence for the occurrence of parthenogenetic populations in Trichadenotecnum majus. All the sexed $(>200)$ specimens sampled in this study and $>100$ specimens in an oak forest study conducted in SW Finland (Kanervo \& Rinne 1996) were females. Parthenogenetic populations of T. majus are known to occur in Turku area in SW Finland (Nokkala \& Golub 2002). Parthenogenetic populations seem to be common in southern and central Finland. Males of T. majus are known to occur in Central Europe (Günther 1974).

\section{Habitat preferences of psocids occurring in old-growth forests}

We compared the OGF material of this study to the unpublished data set by JK. The latter material included 9460 individuals of 30 psocopteran species that were also found in the OGF samples. The proportions of the following species were clearly 
higher in the OGF material than in the reference data set: Elipsocus abdominalis Reuter (OGF $15.4 \%$, JK 5.4\%), Reuterella helvimacula (Enderlein) (OGF 6.4\%, JK 2.6\%), Stenopsocus lachlani Kolbe (OGF 8.7\%, JK 3.4\%) and Trichadenotecnum majus (Kolbe) (OGF 8.6\%, JK $3.3 \%$ ). These species possibly prefer - but are not restricted to - old-growth forests.

Also Laine et al. (1993) and Mückstein \& Holuša (2003) found that Stenopsocus lachlani is associated with old forests. Reuterella helvimacula was most abundant in old forests in Laine et al.'s (1993) data. Unlike in the present study, previous authors (Laine et al. 1993, Mückstein \& Holuša 2003) found Trichadenotecnum majus to be less abundant in old than in young forests. Trichadenotecnum germanicum is mentioned to occur on old trees (Günther 1974), but its proportion in the OGF material was similar to that in JK's data base (1.4 vs. $1.1 \%)$. The majority (26 out of 32) of psocopteran species sampled in this study seem to have no preference for old-growth forests nor for old trees.

\subsection{Psocidus flavonimbatus}

Psocus flavonimbatus Rostock, 1879 was re-described on the basis of 38 specimens found in the material of this study in 1997, 1998 and 2000 (Lienhard \& Kanervo 2002). The generic placement of this species is still uncertain because the male genitalia are unknown. Lienhard \& Smithers (2002) refer this species to the genus Psocidus. This species has been found in four localities in Kuhmo: Teeri-Lososuo (7091:608), Jauhovaara (7106:603), Särkijärvi (7111:622) and Juortanansalo (7167:635-6). Altogether 34 specimens were collected in Teeri-Lososuo area in 1998 and 2000. Three additional females of Psocidus flavonimbatus were found in the beating sample in Ok: Kuhmo, Teeri-Lososuo 7091:608 (M. Salo leg.): $1 q$ 15.VII.2003, 1 + 25.VII.2003 and 19 4.VIII.2003; all three specimens from Norway spruce. An additional female was reared from a sample of decaying spruce in Ok: Kuhmo, Juortanansalo 7167:635-6, 4.11.VIII.2004.

Psocidus flavonimbatus has been found so far only in spruce-dominated old-growth forests of
Kuhmo region, eastern Central Finland. We are not aware of any other individuals of this species anywhere else except for the holotype from Estonia (Rostock 1879, see also Lienhard \& Kanervo 2002). The large Finnish data sets by JK from SW Finland (see Material and methods) and by Laine et al. (1993) from North Finland do not contain this species. Psocidus flavonimbatus might hence be a true OGF species, possibly with an eastern range of distribution.

The typical habitat of Psocidus flavonimbatus is middle-boreal spruce-dominated old-growth forest, where Norway spruce (Picea abies) is mixed with Scots pine (Pinus sylvestris), birch (Betula pubescens and B. pendula), trembling aspen (Populus tremula), goat willow (Salix caprea), juniper (Juniperus communis) and rowan (Sorbus aucuparia). The ground vegetation is dominated by ericaceous plants such as Vaccinium myrtillus, V. uliginosum, Ledum palustre and $V$. vitis-idaea. The evidence of host tree association of $P$. flavonimbatus is somewhat puzzling: 37 out of the 41 Psocidus flavonimbatus specimens were collected by window traps placed directly onto trunks of old living aspens. However in the beating sample of 2003, where aspen, goat willow and spruce trees as well as juniper bushes were sampled, all three specimens of $P$. flavonimbatus were found on spruce. The reared specimen (see above) was presumably at the nymphal stage when the piece of decaying spruce was collected and transferred into rearing facilities. In conclusion, Norway spruce seems to be suitable host tree for both adults and nymphs, while the evidence for the connection between P. flavonimbatus and trembling aspen is more circumstantial.

\section{Discussion}

\subsection{Host-tree associations of psocids occurring in old-growth forests}

\subsubsection{Picea abies}

According to Günther (1974), the following species represented in our material occur predominantly on spruce: Valenzuela despaxi, Enderleinella obsoleta (also on fir), Stenopsocus lach- 
lani and Peripsocus didymus. Also the few Central European specimens of Trichadenotecnum incognitum collected by 1974 were all found on spruce (Günther 1974). In the beating sample of this study more than $80 \%$ of psocopteran specimens were collected from Norway spruce. The most abundant species in this sample were Peripsocus didymus and Valenzuela despaxi. In the data set by JK the following species are considered to be associated with spruce (i.e., more than $50 \%$ of specimens were found on spruce): Valenzuela burmeisteri, V. despaxi, Enderleinella obsoleta, Reuterella helvimacula, Trichadenotecnum incognitum and Peripsocus didymus. Anonby (1995) describes the habitat of Peripsocus didymus as follows: "All the West Norwegian finds have taken place in, or close to, dense plantations of Norway spruce Picea abies, a tree species not indigenous to the West Norwegian districts in question".

This is the only species that was clearly more abundant in the window traps of Häme, situated in coniferous forests, than in those window traps in Kuhmo that were placed on trunks of aspens in spruce-dominated forests. Other psocopteran species in the beating sample, which were most abundant on Picea abies, may not be dependent on spruce. The rare species Psocidus flavonimbatus, only reported from old-growth forests of Kuhmo region in eastern Central Finland, might be associated with spruce rather than with aspen (see previous Section).

\subsubsection{Populus tremula}

In this study 1,605 specimens of 26 species have been collected by window traps placed directly onto old aspen trees. In the reference data set by JK, 444 specimens of 17 species are listed from trembling aspen. None of these species seems to have a clear preference for aspen. Many common psocid species, e.g. Stenopsocus lachlani and Elipsocus abdominalis, were also common in the window traps attached to aspens. The proportion of Valenzuela burmeisteri and Reuterella helvimacula was clearly higher in the material of the Aspen study than in JK's reference data set from SW Finland. However, both species seem to be associated with spruce rather than aspen, as discussed above.

\subsection{Species associated with old-growth forests?}

Our extensive sampling in middle-boreal oldgrowth forests of Finland, using several collecting methods including light-, window- and baittrapping as well as beating, yielded 31 out of 69 (45\%) recognized psocopteran species reported from Finland. Elipsocus abdominalis, Reuterella helvimacula, Stenopsocus lachlani and Trichadenotecnum majus were clearly more abundant in our samples than in the reference data set by JK. Reuterella helvimacula (Laine et al. 1993) and Stenopsocus lachlani (Laine et al. 1993, Mückstein \& Holuša 2003) were also found to be associated with old forests. Further research shall clarify if these four species prefer old-growth forest or simply old trees.

Psocidus flavonimbatus might be a true oldgrowth-forest species, as it - despite considerable sampling effort - has not been collected from managed forests in either southwestern or northern Finland. On the other hand, it is also missing from the North-Finnish old-forest material of Laine et al. (1993). It is not common even in its best-known habitat, the spruce-dominated middle-boreal natural forests of Kuhmo region, eastern Central Finland. Further extensive sampling in both managed and old-growth forests in Kuhmo region shall address the more exact habitat requirements of $P$. flavonimbatus.

Acknowledgements. We wish to thank all those field assistants employed by Friendship Park Research Centre, Kuhmo, who helped us to collect and sort the psocid material. Special thanks to Martti Salo, who conducted much of the beating in Teeri-Lososuo area. Pirjo Appelgren kindly prepared the maps. We are grateful to Mikko Kuussaari who sent the first Psocoptera samples of the Fragmentation study to JK for identification. Veikko Rinne helped us with identification of some psocopterans. Jari Ilmonen gave valuable comments on an earlier draft of the manuscript. Gavin Broad kindly checked the English.

\section{References}

Ahti, T., Hämet-Ahti, L. \& Jalas, J. 1968: Vegetation zones and their sections in northwestern Europe. - Ann. Bot. Fennici 5: 169-211.

Aksenov, D., Karpachevskiy, M., Lloyd, S \& Yaroshenko, A. 1999: The last of the last. The old-growth forests of 
boreal Europe. - Taiga Rescue Network, Jokkmokk. $67 \mathrm{pp}$

Anonby, J. 1995: Norwegian Psocoptera I-A national species list, with preliminary comments on distribution and abundance. - Fauna Norv. Ser. B 42: 49-58.

Broadhead, E. \& Wolda, H. 1985: The diversity of Psocoptera in two tropical forests in Panama. - J. Anim. Ecol. 54: 739-754.

Danks, L. 1968: Catalogue of the Psocoptera of the USSR. — Latv. Ent. 12: 3-18 (in Russian, with English summary).

Esseen, P.-A., Ehnström, B., Ericson, L. \& Sjöberg, K. 1997: Boreal forests. - Ecological Bulletins 46: 1647.

Günther, K. K. 1974: Staubläuse, Psocoptera. — Die Tierwelt Deutschlands, 61. Teil. - Gustav Fischer Verlag, Jena. 314 pp.

Hanski, I. 2005. The shrinking world: Ecological consequences of habitat loss. - International Ecology Institute, Oldendorf/Luhe. 307 pp.

Hedström, L. 1989: Svenska insektfynd, rapport 5. — Ent. Tidskr. 110: 149-155.

Jalas, I.1960: Eine leichtgebaute, leichttransportable Lichtreuse zum Fangen von Schmetterlingen. - Annales Entomol. Fennici 26: 44-50.

Jalas, I. 1991: Perhostenkeräilijän opas. Revised 3rd edition. - Otava, Helsinki. 272 pp. (in Finnish).

Kanervo, J. 1996: Short reports. Taxa new to Finland: Psocoptera. - Entomol. Fennica 7: 1.

Kanervo, J. 1997: Short reports. Taxa new to Finland: Psocoptera. - Entomol. Fennica 8: 1.

Kanervo, J. 2002: Faunistic notes: Psocoptera. - Sahlbergia 7: 37 .

Kanervo, J. \& Rinne, V. 1996: Psocopteran fauna of oak forests in SW Finland. - Sahlbergia 3: 21-23 (in Finnish, with English summary).

Laine, A., Itämies, J. \& Orell, M. 1993: The Psocoptera of Norway spruce (Picea abies) branches in northern Fin- land. — Entomol. Fennica 4: 201-206.

Lienhard, C. 1998: Psocoptères euro-méditerranéens. Fauna de France 83: XX+517 pp.

Lienhard, C. \& Kanervo, J. 2002: Redescription of Psocus flavonimbatus Rostock (Psocoptera: Psocidae) from Finland. - Entomol. Fennica 13: 58-62.

Lienhard, C. \& Smithers, C. N. 2002: Psocoptera (Insecta): World Catalogue and Bibliography. (Instrumenta Biodiversitatis 5). - Muséum d'histoire naturelle, Genève. 745 pp.

Markkanen, S., Vieno, M. \& Walls, M. 2002: Finnish Biodiversity Research Programme FIBRE 1997-2002. Summary Report. - Biodiversity Research Programme FIBRE. 154 pp.

Meinander, M. 1978: Brief reports. Finlands Liposcelisarter (Liposcelidae). - Notulae Entomologicae 58: 171-172.

Mückstein, P. \& Holuša, O. 2003: Composition of psocid taxocenoses (Insecta: Psocoptera) in dependence on the level of naturalness of forest ecosystems in the Žiárské vrchy hills. — J. For. Sci. 49: 208-219.

Nokkala, S. \& Golub, N. 2002: Cytogenetics of three parthenogenetic Psocid species (Psocoptera, Psocomorpha). - Hereditas 137: 198-201.

Rassi, P., Alanen, A., Kanerva, T. \& Mannerkoski, I. (eds.) 2001: Suomen lajien uhanalaisuus 2000. Ympäristöministeriö \& Suomen ympäristökeskus, Helsinki. 432 pp.

Rostock, M. 1879: Über eine besondere nordrussische Psocus-art. — Ent. Nachr. 5: 129-130.

Savolainen, R. 2001: Kuusen (Picea abies) oksilla esiintyvät jäytiäiset (Psocoptera) Siilinjärven alueella ja niiden yhteys ilmansaasteisiin. - Master's thesis, University of Oulu, Department of Biology. 58 pp.

Tilman, D., May, R. M., Lehman, C. L. \& Nowak, M. A. 1994: Habitat destruction and the extinction debt. Nature 371: 65-66. 